\title{
CFRP の繊維配置最適化による耐水環境性向上*
}

\author{
高橋和也光，中村孝*2 \\ 小 熊 博 幸*2, 高 木 敏 勝*3
}

\section{Improvement in Resistant Properties of CFRP against Aqueous Environment by Optimizing Fiber Placement}

\author{
Kazuya TAKAHASHI, Takashi NAKAMURA*4, \\ Hiroyuki OGUMA and Toshikatu TAKAGI \\ ${ }^{* 4}$ Division of Mechanical and Space Engineering, \\ Graduate School of Engineering, Hokkaido University, \\ N13, W8, Kita-ku, Sapporo-shi, Hokkaido, 060-8628 Japan
}

\begin{abstract}
To clarify the water absorption properties of CFRP and resin, water immersion tests of resin and CFRP were conducted. The cross-section of CFRP was observed to understand fiber placement inside CFRP. To analyze the water absorption of CFRP with different fiber placements, a new software program which used a diffusion coefficient and a maximum water concentration in resin was developed. The calculated data were coincident with the experimental water absorption. Therefore, the adequacy of this program was confirmed. The analysis using this program suggested that fiber should be placed as close as the surface to improve the resistant properties of CFRP against aqueous environment.
\end{abstract}

Key Words : Composite Material, Numerical Analysis, Water Absorbtion, Carbon Fiber Placement

\section{1. 粕}

CFRP は近年，機械分野のみではなく，土木分野な どにも用いられるようになり，その使用範囲は拡大し ている. 土木分野における使用例としては，橋脚の柱 に巻き付けるなどの耐震補強材としての利用が挙げ られる. このような場合には, CFRP は湿気などの水 環境に曝される. CFRP が水に曝されると，吸水によ り強度低下を生じる事が知られている(1).ここで，吸 水を抑えることができれば，CFRP の耐水環境性の向 上，すなわち水環境に曝される事による強度低下の抑 制が期待される. CFRP の吸水現象に影響を与える因 子として, 樹脂の化学構造, 炭素繊維の表面処理剤, CFRP 内部での炭素䋐維の配置などが考えられる.

本研究では, 而水環境性を向上させる炭素繊維の最 適な配置方法を提案する事を目的とした. そのために, CFRP の吸水挙動を樹脂の最大水分濃度, 拡散係数お よび炭素䋐維の配置状態から解析するプログラムを 開発した. そして，そのプログラムの妥当性を確認す るために，樹脂およびCFRP の吸水挙動を把握するた めの浸漬実験, ならびに CFRP の断面観察を行った.

* 原稿受付 2009 年 9 月 30 日.

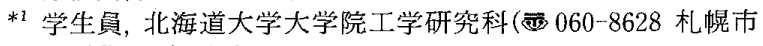
北区北 13 条西 8 ).

$* 2$ 正員, 北海道大学大学院工学研究科.

$* 3$ 北海道大学大学院工学研究科.

E-mail: nakamut@eng.hokudai.ac.jp

\section{2. 実検方法}

吸水特性を把握寸る為に（1）樹脂およびCFRP の吸 水特性の取得ならびに (2) CFRP の断面観察を行った.

2.1 試験片 浸漬試験の為に2 種類の試験片(樹 脂試験片およびCFRP 訊験片) を作製した. 両試験片 の母材にエポキシ樹脂 EPOTHERM ${ }^{\mathrm{m}}$ （三菱化学社製） を使用した．樹脂詰験片は平板に樹脂を均一に広げた 後に硬化させて製作した板材を短冊状に切り出す事 で製作した. CFRP 試験片の強化材には，繊維方向が 一方向に揃った炭素繊維シートReplark ${ }^{\mathrm{TM} M}$ (三菱化学社 製）を使用した. 4 枚の繊維シートを[0,0 $]_{\mathrm{s}}$ 方向に積層 し硬化させた板材を短冊状に切断した. ここで試験片 長手方向と瀻維方向を一致させた. 試験片の切断面に \#400 のエメリ一紙で研磨仕上げを施した. 雨試験片の 寸法 (長さ $\times$ 幅) は, $250 \mathrm{~mm} \times 25 \mathrm{~mm}$ であり, 厚さ は樹脂試験片: $1.1 \mathrm{~mm}, \mathrm{CFRP}$ 試験片: $1.7 \mathrm{~mm}$ である.

\section{$2 \cdot 2$ 浸洨実検 浸漬実験は, ASTM D5229/D} 5229M-92 に準拠して実施した. 恒温槽には東京理化 器械株式会社製 NTT-20G を用いた. 製作した試験片 を湿度 3\%の環境で約 3 ヶ月程度十分乾燥させた後, $20^{\circ} \mathrm{C}$ に保持した脱イオン水中に約 4 ケ間浸漬した。

$2 \cdot 3$ 筫测定 質量測定には電子天秤（ザルト リウス社製 LA130S-F）を用いた. 浸漬させた試験片 を水から定期的に取り出し，質量を測定した. 


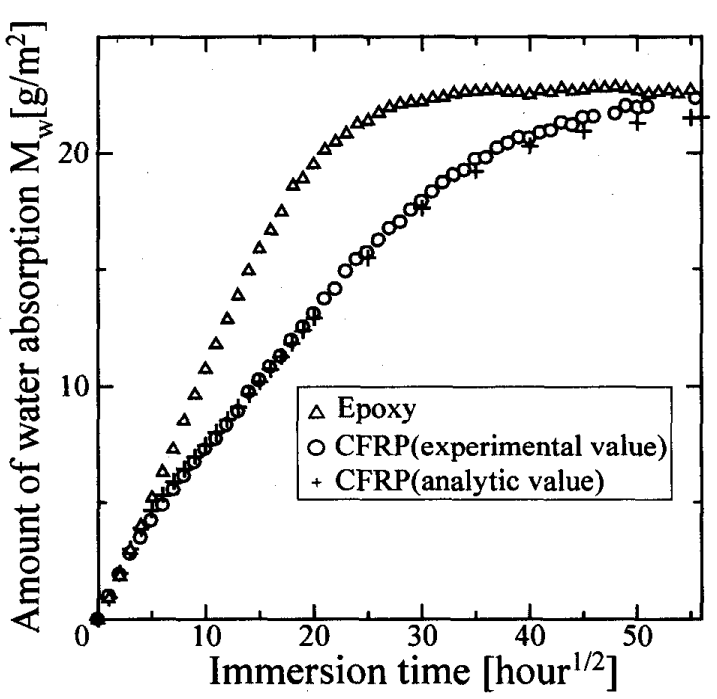

Fig.1 Moisture content during immersion tests

\section{4 所面覞宗光学顕微鏡および走査型電子} 顕微鏡(SEM)により試験片断面を観察し, 浸漬させた CFRP 内部の繊維の配置を特定した.

\section{3. 実験結果}

3-1 浸漬試倹浸漬試験結果を図 1 に示寸. 縦 軸は浸漬開始からの吸水量を表面積 $(2 \times$ 長さ×幅) $A$ で除した值 $M_{w}\left[\mathrm{~g} / \mathrm{m}^{2}\right]$, 横軸は浸漬時間の平方根 $\left[\mathrm{hour}^{1 / 2}\right]$ である．樹脂試験片の $M_{w}$ (図中 $\triangle$ ） は浸漬開始から 一定の割合 $t=1.09 \mathrm{~g} /\left(\mathrm{m}^{2} \cdot\right.$ hour $\left.^{1 / 2}\right)$ で増加した. その後, $M_{w}$ の増加は緩やかになり, 約 30.0 hour $^{1 / 2}$ 以降ほぼ一 定值 $M_{w, m a x}=22.6 \mathrm{~g} / \mathrm{m}^{2}$ を示した. 拉散係数 $D_{m}\left[\mathrm{~m}^{2} / \mathrm{hour}\right]$ および最大水分濃度 $\rho_{m}\left[\mathrm{~g} / \mathrm{m}^{3}\right]$ を次式で求めた. ここで, $L$ は試験片厚さ $[\mathrm{m}], V$ は試験片体積 $\left[\mathrm{m}^{3}\right]$ である.

$$
\begin{aligned}
& D_{m}=\pi\left(\frac{L}{4 M_{w, \max }}\right)^{2} d^{2} \\
& \rho_{m}=\frac{A M_{m}}{V}
\end{aligned}
$$

$D_{m}=6.61 \times 10^{-10} \mathrm{~m}^{2} /$ hour, $\rho_{m}=37.5 \times 10^{3} \mathrm{~g} / \mathrm{m}^{3}$ が得られた.

3-2 断面激宗 CFRP 試験片の断面を図 2 に示 す. 図の鉛直方向が厚さ方向, 横方向が幅力向である. そして, 紙面の法線方向が長さ方向（繊維方向）に対 応する. CFRP 試験片の表面を図中の黒の破線で示す. 繊維はCFRP 試験片内部で楕円状の束として存在して いる事が確認された. 特に図中の白の点線で囲った束 の形状および位置は次の通りであった。

- 楕円の長軸 $\left(L_{1}\right)$, 短軸 $\left(L_{2}\right): 3.40 \mathrm{~mm}, 0.33 \mathrm{~mm}$

- 束の端と隣の束の端間の距離 $\left(L_{3}\right) \quad: 0.38 \mathrm{~mm}$

- 最も表面に近い束の下端と 2 層目の束の上端の間隔

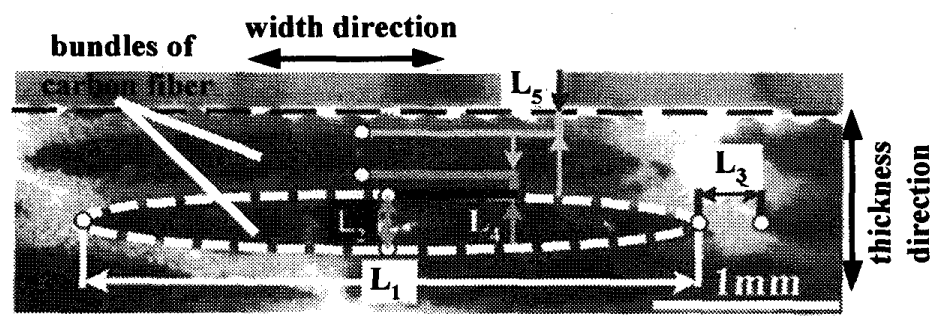

Fig.2 Cross-section observation of CFRP

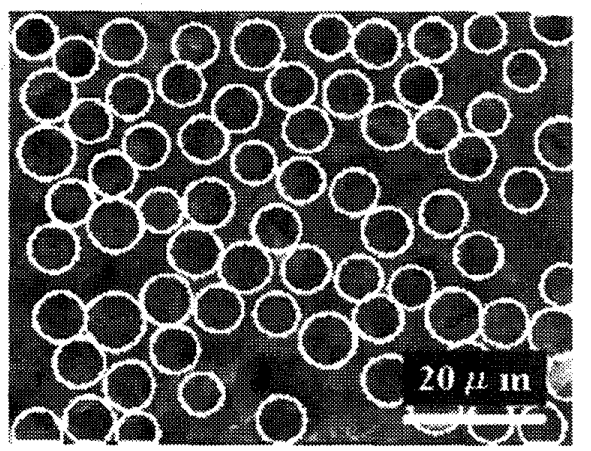

Fig.3 Magnified photograph of fiber bundle

$\left(L_{4}\right) \quad: 0.09 \mathrm{~mm}$

- 表面と表面に最も近い炭素繊維の束の上端の間隔 $\left(L_{5}\right): 0.09 \mathrm{~mm}$

本試験で使用した部材で製作した CFRP の断面の束 の部分を拡大した画像を図 3 に示す．図中の○は，炭 素繊維の断面である. 束内部での炭素繊維の面積率を 求めた結果，約 $56 \%$ となった.

\section{4. 解析手法}

CFRP 内部の時間経過に伴う水分濃度分布の変化を 2 次元拡散問題とし樹脂の最大水分濃度, 拡散係数お よひ繊維配置から解析するプログラムを開発した。

図 4 に CFRP の断面の模式図を示寸. 図中 $\mathrm{x}, \mathrm{y}, \mathrm{z}$ 方向はそれぞれ厚さ, 幅, 長さ方向に対応する. また, 図の上端が CFRP 表面を示寸，CFRP が水に曝された 時の水分濃度を, 次の方法で算出する.

(1)断面を厚さ $\Delta x$, 幅 $\Delta y$ の要素に分割する. 樹脂に相 当する部分を要素 $\mathrm{R}_{\mathrm{ij}}$ とする．また，繊維に相当する 部分を要素 $\mathrm{C}_{\mathrm{ij}}$ とする.ここで，炭素繊維が吸水しな 、性質を考慮し，要素 $\mathrm{C}_{\mathrm{i}, \mathrm{j}}$ で水の授受がないものとす る $\left(\mathrm{i}_{2} \mathrm{j}=1,2,3 \cdots\right)$

(2)各要素に浸漬させる前の初期水分濃度 $\rho^{1}{ }_{i j}\left[\mathrm{~g} / \mathrm{m}^{3}\right]$ を 設定する. 本研究では試験片を十分乾燥させたので, 全要素の初期水分濃度を 0 と設定した.

(3)任意の時間 $t$ から $\Delta t$ 後 $\left(n\right.$ ステップ後)の要素 $\mathrm{R}_{\mathrm{ij}}$ の水 分濃度 $\rho^{n+1}{ }_{i j}$ を算出する $(\mathrm{n}=1,2,3, \cdots)$

要素 $\mathrm{R}_{\mathrm{ij}}$ 内で質量保存則より次の関係が成り立つ.

(単位時間当たりに増加する水分量) =

（流入質量流束）－（流出質量流束） 


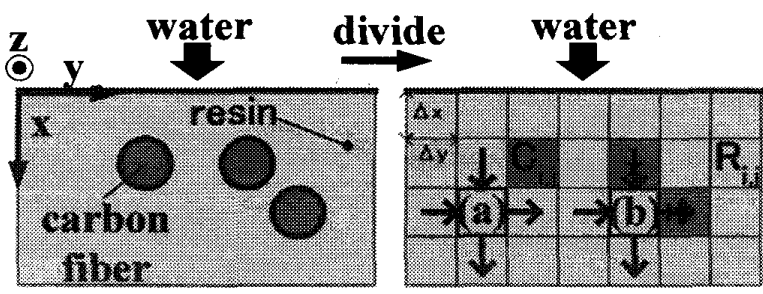

Fig.4 Cross-section of CFRP

$$
\begin{gathered}
\frac{\rho_{i, j}^{n+1}-\rho_{t, j}^{n}}{\Delta t} \Delta x \Delta y=\left(q_{i}^{n} \Delta y+q_{j}^{n} \Delta x\right)-\left(q_{i+1}^{n} \Delta y+q_{j+1}^{n} \Delta x\right) \\
\therefore \rho_{i, j}^{n+1}=\rho_{i, j}^{n}+\frac{\Delta t}{\Delta x \Delta y}\left[\left(q_{i}^{n} \Delta y+q_{j}^{n} \Delta x\right)-\left(q_{i+1}^{n} \Delta y+q_{j+1}^{n} \Delta x\right)\right]
\end{gathered}
$$

流束 $q\left[\mathrm{~kg} /\left(\mathrm{m}^{2} \cdot \mathrm{s}\right)\right]$ は Fick の法則より 次式で求める ${ }^{(2)}$.

$$
q_{i}^{n}=D_{m} \frac{\rho_{i, j}^{n}-\rho_{i-1, j}^{n}}{\Delta x} \quad q_{j}^{n}=D_{m} \frac{\rho_{i, j}^{n}-\rho_{i, j-1}^{n}}{\Delta y}
$$

一方, 要素 $\mathrm{R}_{\mathrm{i} \mathrm{j}}$ の周りに要素 $\mathrm{C}_{\mathrm{i}, \mathrm{j}}$ が存在する場合は, 要素 $\mathrm{C}_{\mathrm{i}, \mathrm{j}}$ に出入りする流束は 0 とする.ここで， $D_{m}$ お よび $\rho_{m}$ は浸漬試験より得た值を用いた。

解析に用いたモデルを図5に示す. 図の上端はCFRP 表面, 下端はCFRP の中央に対応する. 図の左右端は, 束の端と隣の束の端間を 2 等分する面に対応する. 厚 さ, 幅, 長さ力向は, 図 3 と同じである. 要素長さは, 厚さ方向幅力向共に $10 \mu \mathrm{m}$ である. 東の寸法および位 置は，断面観察時の值 $L_{1} \sim L_{5}$ を採用した。 また，束内 部に要素 $\mathrm{C}_{\mathrm{i} j}$ を面積率が約 $56 \%$ になるように均等に配 置した。 上下端および左右端の境界条件を以下に示す。

$$
\rho_{i, j}^{n}=\rho_{m} \text { (上端), } q_{i}^{n}=0 \text { (下端) }, q_{j}^{n}=0 \text { (左右端) }
$$

\section{5. 解析結果および考察}

解析結果を図 1 に示寸. 実験值 (図中, ○印) と解 析值（+印）はほぼ一致する事が確認され，プログラ ムの妥当性が示された. そこで，この手法により耐水 環境性を向上させる炭素繊維の配置方法を検討する.

式(4)より,CFRP 内部への単位時間当りの流入量は, 表面の濃度とその直下の濃度の差に依存する。つまり， 表面直下の水分濃度を速く飽和可能ならば，単位時間 当りの吸水量は小さくなる，一方，CFRP 板における 吸水過程で以下の現象が起きていると考えられる.

(1)表面から流入した水は，近くに拡散の障害となる炭 素瀻維が無いために，樹脂の中を厚さ方向に浸透する. (2)時間の経過に伴い，水は表面に最も近い炭素繊維の 束の近傍まで浸透する.

(3)炭素繊維は吸水しないため，水の厚さ方向への浸透 が困難になる。

(4)表面近傍の水分濃度が飽和に近づく

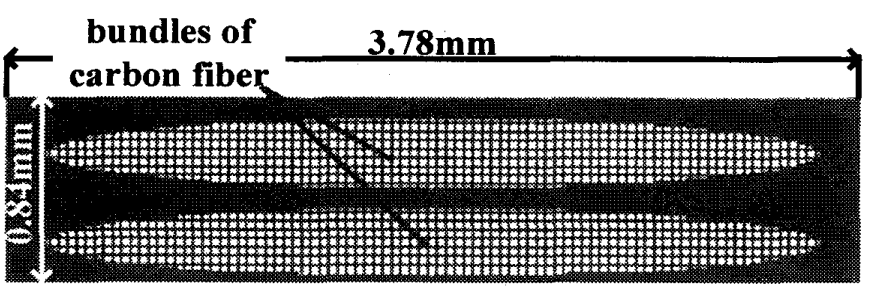

Fig.5 Analysis model

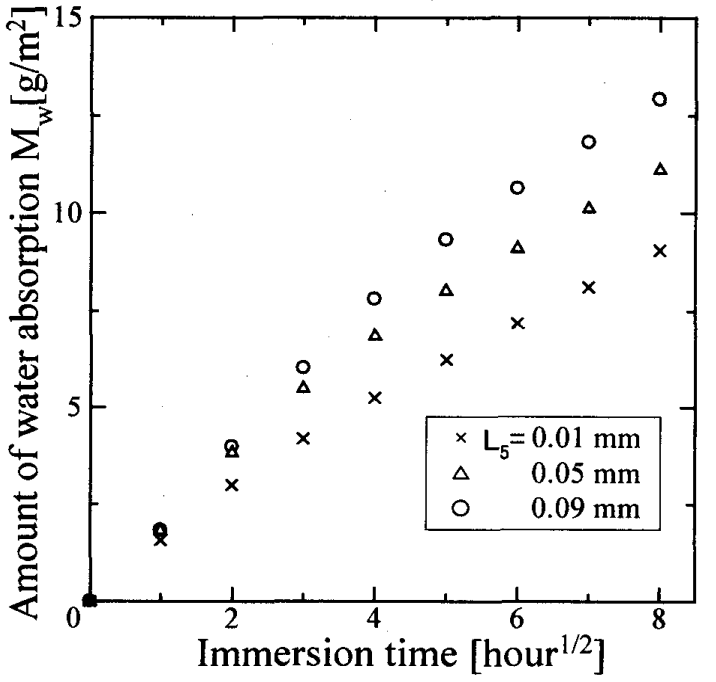

Fig.6 Relation between speed of water absorption and $L_{5}$

つまり，表面に近い位置へ繊維を配置する事により 厚さ方向への水の浸透を抑制可能と考えられる. そこ で, 図 5 の解析モデルにおいて, 表面と表面に最も近 い炭素繊維の束の上端までの間隔 $L_{5}$ を変えて, 吸水挙 動の変化を調べた. 解析結果を図 6 に示す． $L_{5}$ が小さ くなるにつれて，吸水速度が低くなる傾向が確認され た. 以上より，炭素繊維をできる限り表面近くに配置 する事で耐水環境性を向上できる可能性を示した。

\section{6. 結言}

CFRP の耐水環境性を向上させる最適な緎維配置方 法を提案する事を目的に，浸漬試験ならびに吸水挙動 を解析するプログラムの開発を行った. 浸漬試験の吸 水挙動と解析結果はほぼ一致し, 本プログラムの妥当 性が示された．本プログラムを用いて吸水特性を解析 した結果, 繊維を出来る限り表面近くに配置する事で, CFRP の耐水環境性が向上する可能性が示された。

\section{文献}

(1) Toshikatu, T., Toshio, T., Kazuya, T., Hiroyuki, O. and Takashi, N., Effect of Aqueous Environment on Mechanical Properties of Carbon Fiber Reinforced Plastic, Proceedings of the 47th Hokkaido Branch Meeting of the Japan Society of Mechanical Engineering, No.082-2 (2008), pp.39-40.

(2) The Japan Society of Mechanical Engineering, JSME Text Series: Heat Transfer, (2005), p.164. 